\title{
DAYA VIGORITAS BENIH Acacia crassicarpa A.Cunn.Ex Benth. DARI BEBERAPA SUMBER BENIH
}

\author{
Vigority of Acacia crassicarpa A.Cunn. Ex Benth. Seed from Several Seed Sources \\ Naning Yuniarti, M. Zanzibar, Megawati ${ }^{1)}$ dan/and Budi Leksono ${ }^{2)}$ \\ ${ }^{1)}$ Balai Penelitian dan Pengembangan Teknologi Perbenihan Tanaman Hutan \\ Jl. Pakuan, Ciheuleut PO. BOX. 105, Bogor 16001, Jawa Barat, Indonesia \\ Telp. (0251) 8327768, Fax. (0251) 8327768 \\ ${ }^{2)}$ Balai Besar Penelitian dan Pengembangan Bioteknologi dan Pemuliaan Tanaman Hutan \\ Jl. Palagan Tentara Pelajar Km. 15 Purwobinangun, Pakem, Sleman, Yogyakarta, Indonesia
} Telp. (0274) 895954, Fax. (0274) 896080

Email : naningbtp@yahoo.co.id; muhammadzanzibar@yahoo.com;mg_btp@yahoo.con; boedyleksono@yahoo.com; breeding@biotifor.or.id

Tanggal diterima : 29 Desember 2014; Tanggal direvisi : 24 November 2016; Tanggal disetujui : 5 Desember 2016

\begin{abstract}
Seed vigor testing become important component of seed analysis as seed vigor affects the ability of seeds to growth and to reach normal productivity in sub optimum conditions. This research aimed to determine the growth strenght vigor and the storability vigor of the Acacia crassicarpa A.Cunn.Ex Benth seeds from five seeds sources. The experimental was designed using completely randomized factorial design with 4 replication. Each replication consisted of 100 seeds. The results showed that seeds from seedling seed orchards (sso) had better vigor than seeds from production area. Growth strength vigor of sso's seeds increased germination rate by $11 \%$ and speed germination by 0,8\% per etmal. Storability vigor of sso's seeds increased germination rate by $12 \%$ and speed germination by $0,84 \%$ per etmal.
\end{abstract}

Keywords: Acacia crassicarpa, seed, seed source and vigor

\begin{abstract}
ABSTRAK
Pengujian vigor benih menjadi komponen penting dari analisis benih karena vigor benih mempengaruhi kemampuan benih untuk tumbuh dan berproduksi normal pada kondisi sub optimal. Penelitian ini bertujuan untuk mengetahui vigor kekuatan tumbuh relatif dan vigor daya simpan relatif pada benih Acacia crassicarpa A.Cunn.Ex Benth dari 5 sumber benih. Rancangan percobaan yang digunakan adalah rancangan acak lengkap pola faktorial dengan ulangan 4 kali, setiap ulangan terdiri dari 100 benih. Hasil penelitian menunjukkan bahwa benih $A$. crassicarpa yang berasal dari sumber benih kebun benih semai (KBS) memiliki vigor yang lebih baik dibandingkan dengan benih dari areal produksi benih (APB). Vigor kekuatan tumbuh benih KBS memiliki peningkatan daya berkecambah sebesar $11 \%$ dan t kecepatan berkecambah sebesar $0,8 \%$ per etmal. Vigor daya simpan benih dari KBS memiliki peningkatan daya berkecambah sebesar $12 \%$ dan kecepatan berkecambah sebesar $0,84 \%$ per etmal.
\end{abstract}

Kata kunci: Acacia crassicarpa, benih, vigor dan sumber benih

\section{PENDAhuluan}

Benih unggul umumnya diperoleh dari sumber benih yang telah dimuliakan. Sampai saat ini, benih tanaman hutan hasil pemuliaan yang telah diproduksi sebagai unggulan tanaman penghasil pulp diantaranya adalah Acacia crassicarpa A.Cunn.Ex Benth (Yuniarti et al., 2013). Benih dengan vigoritas tinggi akan mampu berproduksi normal pada kondisi sub optimum dan di atas kondisi normal, memiliki kemampuan tumbuh serempak, cepat serta lebih tahan untuk disimpan dalam kondisi yang tidak ideal. Uji vigor sangat tepat diaplikasikan pada sumber-sumber benih yang telah dimuliakan, misalnya KBS. Pada sumber benih tersebut, besaran vigor harus mampu didefenisikan kualitas fisiologis dan genetiknya karena 
pengorbanan mendapatkan benih-benih tersebut relatif tinggi. Benih vigor yang dicirikan oleh produksi yang unggul harus dapat diinformasikan lebih dini bagi konsumen dan harus bisa disimulasi kinerjanya, seperti kinerja fisik, fisiologis dan genetik. Vigor benih yang tinggi akan menghasilkan tanaman yang baik.

Benih yang berasal dari KBS memiliki viabilitas dan vigor benih yang lebih baik dibandingkan benih yang berasal dari tegakan benih teridentifikasi, contohnya pada benih Pinus merkusii (Nurhasybi et al., 2008). Vigor benih merupakan keadaan fisiologi yang ditentukan oleh faktor genetik dan faktor lingkungan (Madauna, 2007). Peubah vigor benih terdiri atas vigor kekuatan tumbuh dan daya simpan. Vigor benih dapat diindikasikan misalnya dengan tolok ukur laju perkecambahan, keserempakan tumbuh. Daya simpan Vigor dapat diindikasikan dengan tolok ukur daya hantar listrik, vigor benih terhadap deraan etanol atu fisik dan sebagainya (Aryunis, 2009). Menururt Lesilolo et al. (2013) kecepatan tumbuh mengindikasikan vigor kekuatan tumbuh benih, karena benih yang cepat tumbuh lebih mampu menghadapi kondisi lapang yang sub optimal. Vigor benih dapat dibagi dua, yaitu vigor kekuatan tumbuh yang mencerminkan vigor benih bila ditanam di lapangan dan vigor daya simpan yang mencerminkan kemampuan benih untuk berapa lama benih dapat disimpan (Ichsan, 2006).

Tanaman dengan tingkat vigor yang tinggi dapat dilihat dari performansi fenotipis kecambah atau bibitnya, yang selanjutnya dapat berfungsi sebagai landasan pokok untuk ketahanannya terhadap berbagai unsur musibah yang menimpa. Vigor benih untuk kekuatan tumbuh dalam suasana kering dapat merupakan landasan bagi kemampuan tanaman tersebut untuk tumbuh bersaing dengan tumbuhan pengganggu atau pun tanaman lainnya dalam pola tanam multipa vigor benih untuk tumbuh secara spontan merupakan landasan bagi kemampuan tanaman mengabsorpsi sarana produksi makanan secara maksimal sebelum panen. Dalam memanfaatkan unsur sinar matahari khususnya selama periode pengisian dan pemasakan biji. Pada hakekatnya vigor benih harus relevan dengan tingkat produksi, artinya dari benih yang bervigor tinggi akan dapat dicapai tingkat produksi yang tinggi. Vigor benih yang tinggi dicirikan antara lain tahan disimpan lama, tahan terhadap serangan hama penyakit, cepat dan merata tumbuhnya, mampu menghasilkan tanaman dewasa yang normal dan berproduksi baik dalam keadaan lingkungan tumbuh yang sub optimal (Bagod, 2006). Benih memiliki vigor yang tinggi apabila benih memiliki kekuatan tumbuh yang tinggi pula. Kekuatan tumbuh vigor mengindikasikan vigor benih menghadapi kondisi lingkungan yang sub optimum (Sharifabad \& Nodoushan, 2006).

Permasalahan yang dihadapi oleh benih $A$. Crassicarpa, yaitu belum diketahuinya vigor benih dari masing-masing kelas sumber benih, baik sumber benih dari KBS maupun pada sumber benih dari areal produksi benih (APB). Tujuan penelitian ini adalah untuk mengetahui vigor kekuatan tumbuh dan vigor daya simpan beberapa sumber benih $A$. crassicarpa.

\section{METODOLOGI}

\section{A. Tempat dan Waktu}

Benih A. crassicarpa yang digunakan dalam penelitian ini diperoleh dari: (1) KBS Sumatera Selatan, (2) KBS Riau, (3) APB Riau, (4) APB Kalimantan Selatan dan (5) APB Jambi. Data masing-masing sumber benih disajikan pada Tabel 1. 
Tabel (Table) 1. Informasi sumber benih A. crassicarpa yang digunakan dalam penelitian (Information of A. crassicarpa seed source used in the study)

\begin{tabular}{|c|c|c|c|c|c|c|c|c|}
\hline $\begin{array}{c}\text { Lokasi } \\
\text { (Location) }\end{array}$ & $\begin{array}{l}\text { Luas } \\
\text { areal } \\
\text { (Area } \\
\text { large) } \\
\text { (Ha) }\end{array}$ & $\begin{array}{c}\text { Tahun } \\
\text { tanam } \\
\text { (Planting } \\
\text { year) }\end{array}$ & $\begin{array}{c}\text { Asal } \\
\text { benih } \\
\text { (Source } \\
\text { seed) }\end{array}$ & $\begin{array}{c}\text { Klasifikasi } \\
\text { sumber benih } \\
\text { (Classification } \\
\text { of source seed) }\end{array}$ & $\begin{array}{c}\text { Tipe } \\
\text { iklim } \\
\text { (Climate } \\
\text { type) }\end{array}$ & $\begin{array}{c}\text { Jenis } \\
\text { tanah (Soil } \\
\text { kind) }\end{array}$ & $\begin{array}{c}\text { Curah hujan } \\
\text { (Rainfall) } \\
\text { (mm/tahun) } \\
\text { (mm/years) }\end{array}$ & $\begin{array}{c}\text { Ketinggian } \\
\text { tempat } \\
\text { (Altitude) } \\
\text { m dpl } \\
\text { (m a.s.l.) }\end{array}$ \\
\hline $\begin{array}{c}\text { Subanjeriji } \\
\text { (Sumatera } \\
\text { Selatan) }\end{array}$ & 0,6 & 1996 & $\begin{array}{l}\text { Irian } \\
\text { Jaya/ } \\
\text { Papua }\end{array}$ & KBS Generasi I & A & Ultisol & 2.289 & $0-30$ \\
\hline Siak (Riau) & 11,24 & 2007 & $\begin{array}{l}\text { Papua } \\
\text { Nugini } \\
\text { (PNG) }\end{array}$ & KBS Generasi I & A & $\begin{array}{l}\text { Podsolik } \\
\text { merah } \\
\text { kuning }\end{array}$ & 2.260 & $52-58$ \\
\hline $\begin{array}{c}\text { Tanah } \\
\text { Laut/Pleihari } \\
\text { (Kalimantan } \\
\text { Selatan) }\end{array}$ & 21,73 & 1994 & Australia & APB & B & $\begin{array}{l}\text { Podsolik } \\
\text { merah } \\
\text { kuning }\end{array}$ & $2.700-3.000$ & $0-50$ \\
\hline $\begin{array}{l}\text { Tanjung } \\
\text { Jabung Barat } \\
\text { (Jambi) }\end{array}$ & 21,5 & 2002 & $\begin{array}{l}\text { Papua } \\
\text { Nugini } \\
\text { (PNG) }\end{array}$ & APB & A & Ultisol & 2.289 & $0-30$ \\
\hline Siak (Riau) & 9,5 & 2007 & $\begin{array}{l}\text { Papua } \\
\text { Nugini } \\
\text { (PNG) }\end{array}$ & $\mathrm{APB}$ & A & $\begin{array}{l}\text { Podsolik } \\
\text { merah } \\
\text { kuning }\end{array}$ & 2.260 & $52-58$ \\
\hline
\end{tabular}

Pengujian benih dilakukan di Laboratorium dan rumah kaca Balai Penelitian Teknologi Perbenihan Tanaman Hutan Bogor. Penelitian dilaksanakan selama 4 bulan, yaitu bulan Juli sampai dengan Oktober 2011.

\section{B. Bahan dan Alat}

Bahan dan alat yang digunakan dalam penelitian ini adalah benih, batu bata merah, media tanah dan pasir, bak kecambah, sprayer, etanol $(90 \%)$ dan mesin pengusang cepat (MPC IPB 77-1).

\section{Metode}

\section{Pengunduhan polong dan ekstraksi benih}

Polong yang diunduh adalah yang telah berwarna coklat, dengan cara pemanjatan. Ekstraksi benih dilakukan dengan cara buah atau polong dijemur di bawah sinar matahari selama 2-3 hari sampai polong merekah dan benih dapat dikeluarkan secara manual.

\section{Pengujian vigor kekuatan tumbuh}

Vigor kekuatan tumbuh dilakukan di rumah kaca sebagai kondisi optimum sedangkan untuk kondisi sub optimum menggunakan. uji tekanan (metode Hiltner) dan uji kejenuhan. Uji perkecambahan di rumah kaca menggunakan media campuran pasir dan tanah $(1: 1)(\mathrm{v} / \mathrm{v})$. Metode Hiltner sama dengan uji perkecambahan di rumah kaca, namun pada bagian atas media dilapisi dengan hancuran batu bata dan disusun setebal 3-4 cm. Uji kejenuhan benih dilakukan pada media yang sama pada bak kecambah plastik, namun ditempatkan pada ruang gelap di laboratorium (Zanzibar \& Pramono, 2009).

\section{Pengujian vigor daya simpan benih}

Benih yang telah diekstraksi dan sudah kering dilakukan penderaan (accelerated aging). Penderaan benih menggunakan alat mesin pengusang cepat (MPC IPB 77-1). Uap etanol dihembuskan selama 5 menit kemudian dengan udara panas $\left(50^{\circ} \mathrm{C}\right)$ selama 10 menit $[\mathrm{x}(5+10)$ menit], $\mathrm{x}=$ koefisien penderaan, terdiri atas: 0,9 , $12,15,18$ dan 21 kali. Benih yang telah mendapat perlakuan penderaan kemudian dikecambahkan pada media campuran pasir : $\tan a h(1: 1)(\mathrm{v} / \mathrm{v})$.

Ulangan sebanyak 4 kali, masing-masing ulangan terdiri dari 100 butir. Pengamatan dilakukan setiap hari terhadap benih yang telah berkecambah normal. Pengamatan dihentikan apabila selama 7 hari berturut-turut tidak ada lagi benih yang berkecambah. Parameter yang diamati adalah daya berkecambah (DB) dan kecepatan tumbuh $\left(\mathrm{K}_{\mathrm{CT}}\right)$.

\section{Analisis Data}

\section{Vigor kekuatan tumbuh}

Rancangan percobaan yang digunakan adalah faktorial dalam rancangan acak lengkap. 
Faktor pertama adalah sumber benih (SB) terdiri atas 5 taraf:

1. $\mathrm{SB} 1=\operatorname{Siak}(\mathrm{KBS} \mathrm{Riau})$

2. $\mathrm{SB} 2=$ Subanjeriji (KBS Sumatera Selatan)

3. SB3 = Tanah Laut/Pleihari (APB Kalimantan Selatan)

4. $\mathrm{SB} 4=\operatorname{Siak}(\mathrm{APB} \mathrm{Riau})$

5. $\mathrm{SB} 5=$ Tanjung Jabung Barat (APB Jambi)

Faktor kedua ialah uji perkecambahan (M) terdiri atas 3 taraf:

1. $\mathrm{M}_{0}=$ Uji perkecambahan di rumah kaca

2. $\mathrm{M}_{1}=\mathrm{Uji}$ perkecambahan dengan uji tekanan (metode Hiltner)

3. $\mathrm{M}_{2}=\mathrm{Uji}$ perkecambahan dengan uji kejenuhan

\section{Vigor daya simpan}

Rancangan percobaan yang digunakan adalah rancangan faktorial dalam rancangan acak lengkap. Faktor pertama adalah SB terdiri atas 5 taraf:

1. $\mathrm{SB} 1=\operatorname{Siak}(\mathrm{KBS} \mathrm{Riau})$

2. $\mathrm{SB} 2=$ Subanjeriji (KBS Sumatera Selatan)

3. $\mathrm{SB} 3=$ Tanah Laut/Pleihari (APB Kalimantan Selatan)

4. $\mathrm{SB} 4=\operatorname{Siak}(\mathrm{APB} \mathrm{Riau})$

6. $\mathrm{SB} 5=$ Tanjung Jabung Barat (APB Jambi) 6 taraf:

Faktor kedua ialah penderaan (D) terdiri atas

1. $\mathrm{D}_{0}=$ kontrol

2. $\mathrm{D}_{1}=9(5+10)$ menit
3. $\mathrm{D}_{2}=12(5+10)$ menit

4. $\mathrm{D}_{3}=15(5+10)$ menit

5. $\mathrm{D}_{4}=18(5+10)$ menit

6. $\mathrm{D}_{5}=21(5+10)$ menit

\section{HASIL DAN PEMBAHASAN}

\section{A. Hasil}

\section{Vigor kekuatan tumbuh}

Berdasarkan hasil ringkasan analisis sidik ragam menunjukkan bahwa sumber benih, metode uji vigor kekuatan tumbuh dan interaksinya berpengaruh nyata terhadap daya berkecambah dari masing-masing sumber benih. Hal ini berarti terdapat satu atau beberapa perlakuan yang menunjukkan berbeda satu sama lain. Untuk mengetahui lebih lanjut perlakuan yang menimbulkan perbedaan terhadap daya berkecambah, maka dilakukan uji beda rata-rata yang disajikan pada Gambar 1. Berdasarkan hasil interaksi dan uji beda rata-rata menunjukkan bahwa pengujian di rumah kaca cenderung lebih tinggi daripada pengujian menggunakan metode Hiltner dan kejenuhan, dimana nilai rata-rata daya berkecambahnya dari KBS asal Sumatera Selatan dan KBS asal Riau sama tetapi berbeda nyata dengan sumber benih APB Kalimantan Selatan, APB Riau dan APB Jambi. Sumber benih KBS Riau dan KBS Sumatera Selatan telah menghasilkan dara berkecambah yang tinggi (84$86 \%)$.

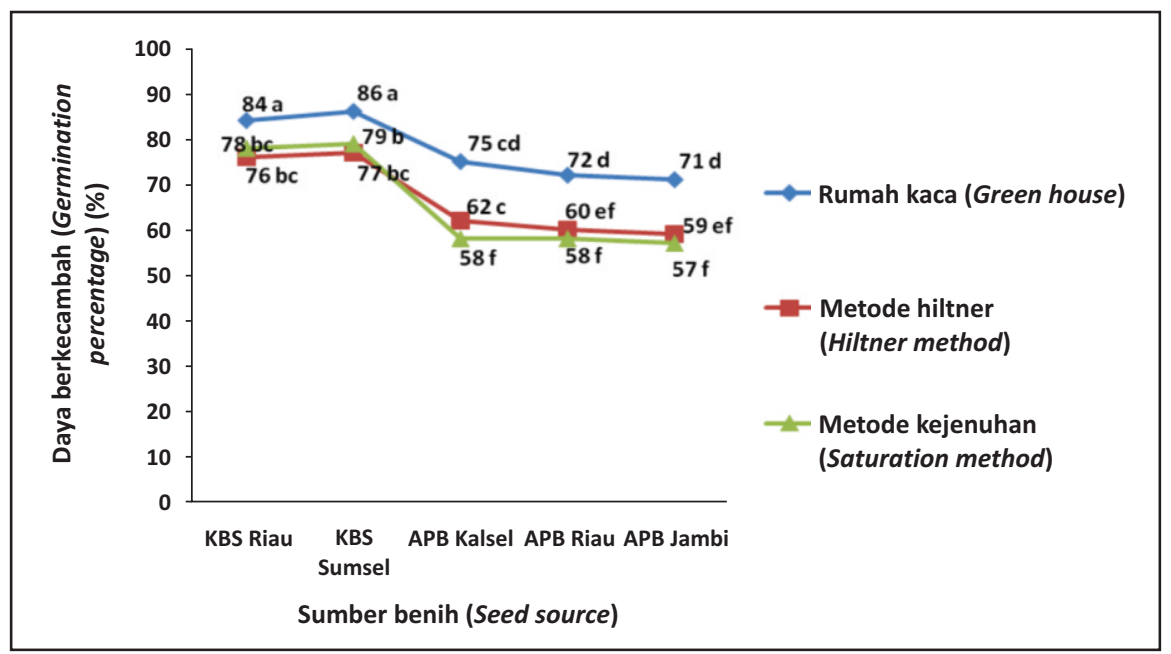

Keterangan(Remaks): Angka-angka yang diikuti oleh huruf yang sama menunjukkan tidak adanya perbedaan nyata pada tingkat kepercayaan 95\% (Values followed by the same letter are not significantly different at $95 \%$ confidencelevel)

Gambar(Figure) 1. Daya berkecambah A. crassicarpa berdasarkan sumber benih dan metode uji vigor kekuatan tumbuh (Germination percentage of A. crassicarpa based on seed sources and the growth strength vigor methods) 
Pengaruhnya terhadap kecepatan berkecambah, diketahui bahwa sumber benih dan metode uji vigor kekuatan tumbuh berpengaruh nyata terhadap kecepatan berkecambah. Untuk mengetahui lebih lanjut perlakuan yang menimbulkan perbedaan terhadap kecepatan berkecambah, maka dilakukan uji beda rata-rata yang disajikan pada Gambar 2 dan Gambar 3. Rata-rata kecepatan berkecambah dari KBS asal Riau dan KBS asal Sumatera Selatan tidak berbeda nyata, namun dengan sumber benih lainnya berbeda nyata.

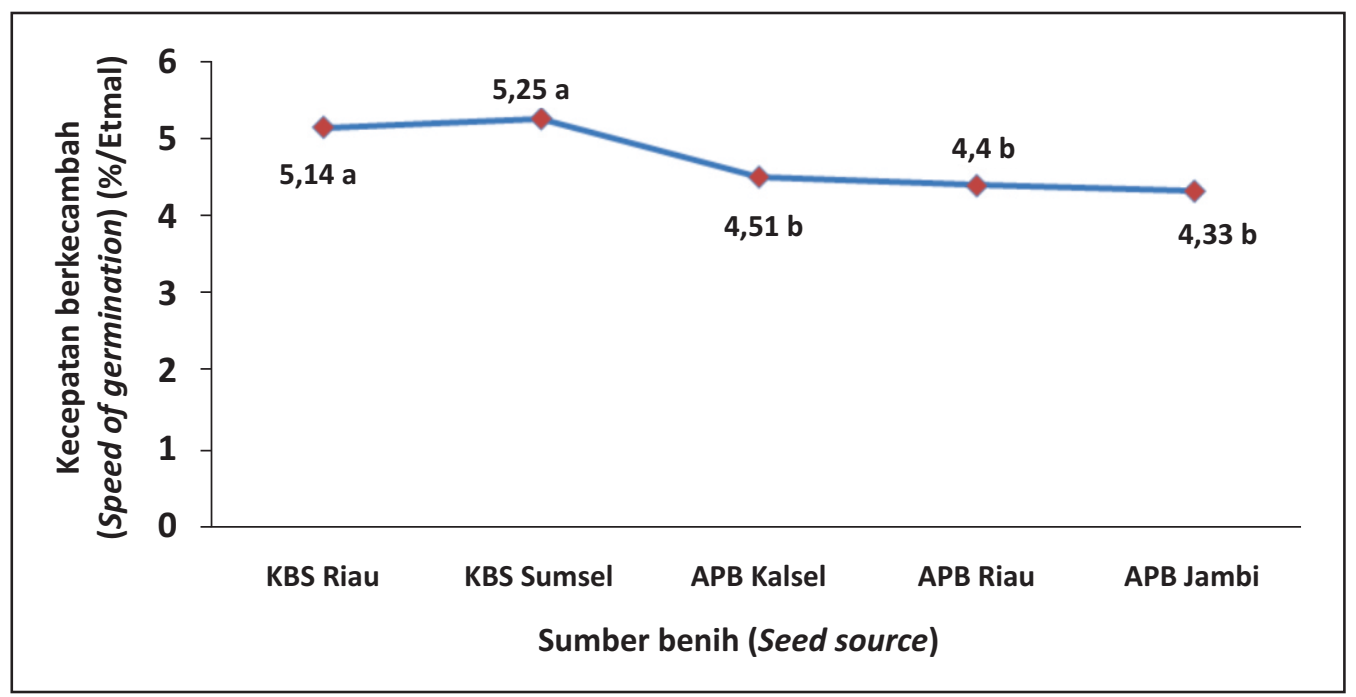

Keterangan(Remaks): Angka-angka yang diikuti oleh huruf yang sama menunjukkan tidak adanya perbedaan nyata pada tingkat kepercayaan 95\% (Values followed by the same letter are not significantly different at 95\% confidencelevel)

Gambar(Figure)2. Kecepatan berkecambah A.crassicarpa berdasarkan sumber benih (Speed germination of A. crassicarpa based on seed sources)

Rata-rata kecepatan berkecambah yang diujikan di rumah kaca tertinggi dan berbeda

signifikan dengan metode pengujian menggunakan metode Hiltner dan kejenuhan (Gambar 3).

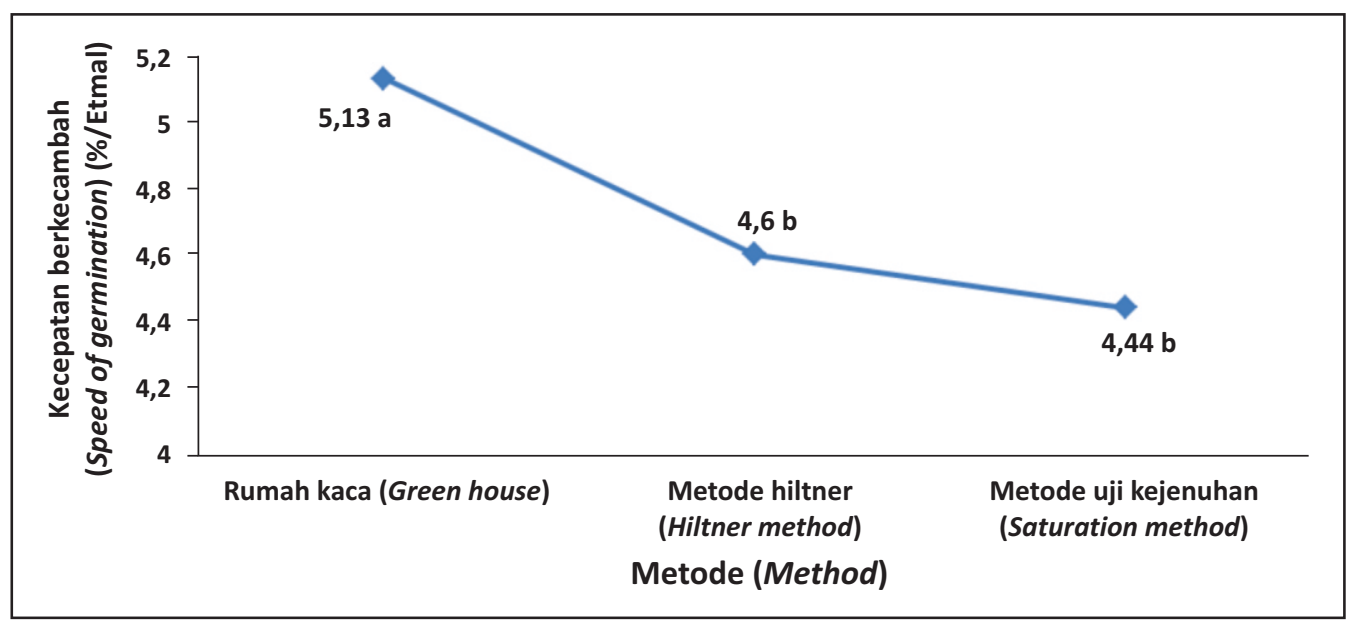

Keterangan(Remaks): Angka-angka yang diikuti oleh huruf yang sama menunjukkan tidak adanya perbedaan nyata pada tingkat kepercayaan $95 \%$ (Values followed by the same letter are not significantly different at $95 \%$ confidencelevel)

Gambar(Figure)3. Kecepatan berkecambah A.crassicarpa berdasarkan metode uji vigor kekuatan tumbuh (Speed germination of $\underline{\mathrm{A}}$. crassicarpa based on growth strength vigor methods) 


\section{Vigor daya simpan}

Hasil analisis sidik ragam menunjukkan bahwa sumber benih, uji vigor daya simpan dan interaksinya berpengaruh nyata terhadap daya berkecambah dari masing-masing sumber benih. Hasil uji lanjut menunjukkan bahwa nilai ratarata daya berkecambah tanpa penderaan (kontrol) berbeda nyata dengan perlakuan lainnya, hal ini terjadi untuk semua sumber benih yang diujikan. Keseluruhan sumber benih yang diujikan ternyata sumber asal KBS Riau dan KBS Sumatera Selatan dengan tanpa perlakuan penderaan merupakan yang terbaik daya berkecambahnya. Hasil uji beda rata-rata disajikan pada Gambar 4.

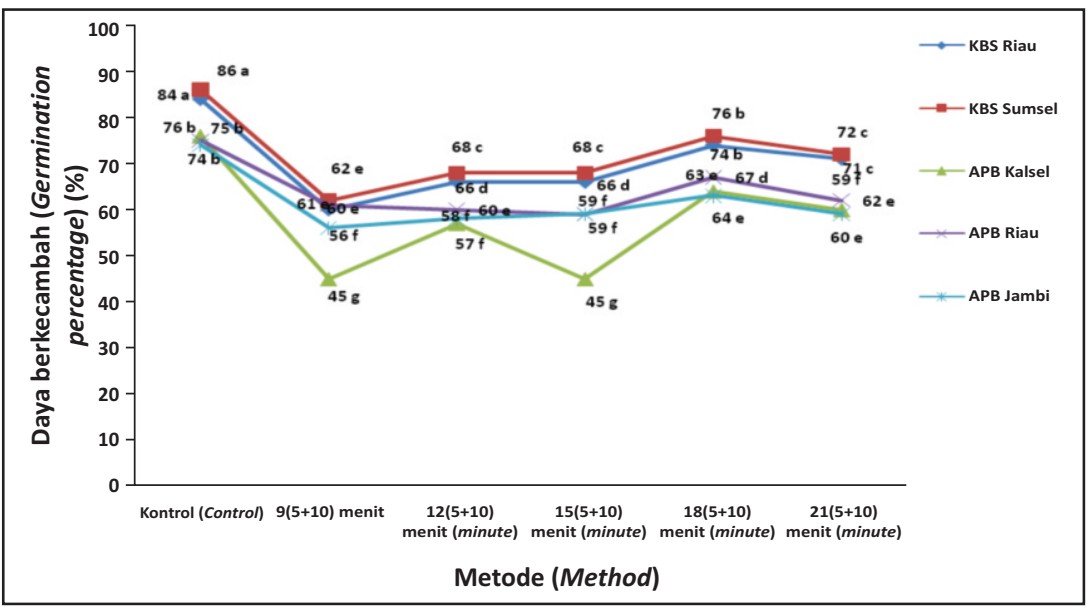

Keterangan(Remaks): Angka-angka yang diikuti oleh huruf yang sama menunjukkan tidak adanya perbedaan nyata pada tingkat kepercayaan 95\% (Values followed by the same letter are not significantly different at 95\% confidencelevel)

Gambar(Figure) 4. Daya berkecambah A. crassicarpa berdasarkan sumber benih dan metode uji vigor daya simpan (Germination percentage of $\underline{\mathrm{A}}$. crassicarpa based on seed sources and the storability vigor methods)

Hasil sidik ragam menunjukkan bahwa sumber benih dan metode uji vigor daya simpan berpengaruh nyata terhadap kecepatan berkecambah. Hasil uji lanjut menunjukkan bahwa rata-rata kecepatan berkecambah benih
KBS asal Riau dan KBS asal Sumatera Selatan tidak berbeda nyata, tetapi dengan sumber benih lainnya berbeda nyata, sehingga benih KBS asal Riau dan KBS asal Sumatera Selatan terbaik (Gambar 5).

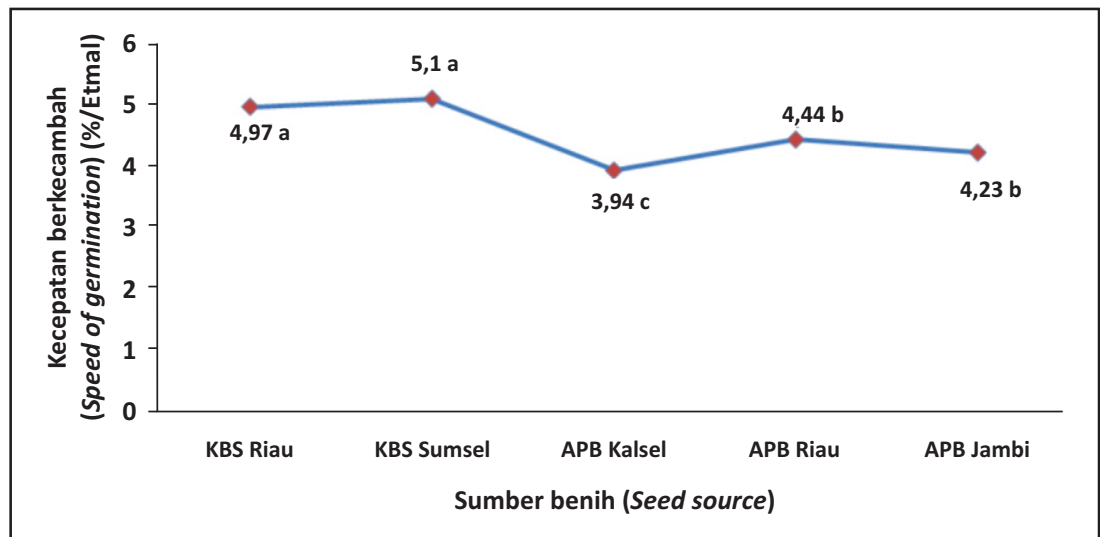

Keterangan(Remaks): Angka-angka yang diikuti oleh huruf yang sama menunjukkan tidak adanya perbedaan nyata pada tingkat kepercayaan 95\% (Values followed by the same letter are not significantly different at 95\% confidencelevel)

Gambar(Figure)5. Kecepatan berkecambah A. crassicarpa berdasarkan sumber benih (Speed

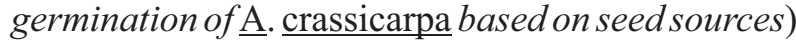


Rata-rata kecepatan berkecambah yang diujikan dengan penderaan $12(5+10)$ menit dan tanpa penderaan (kontrol) tidak beda nyata, tetapi terhadap perlakuan lainnya berbeda (Gambar 6).

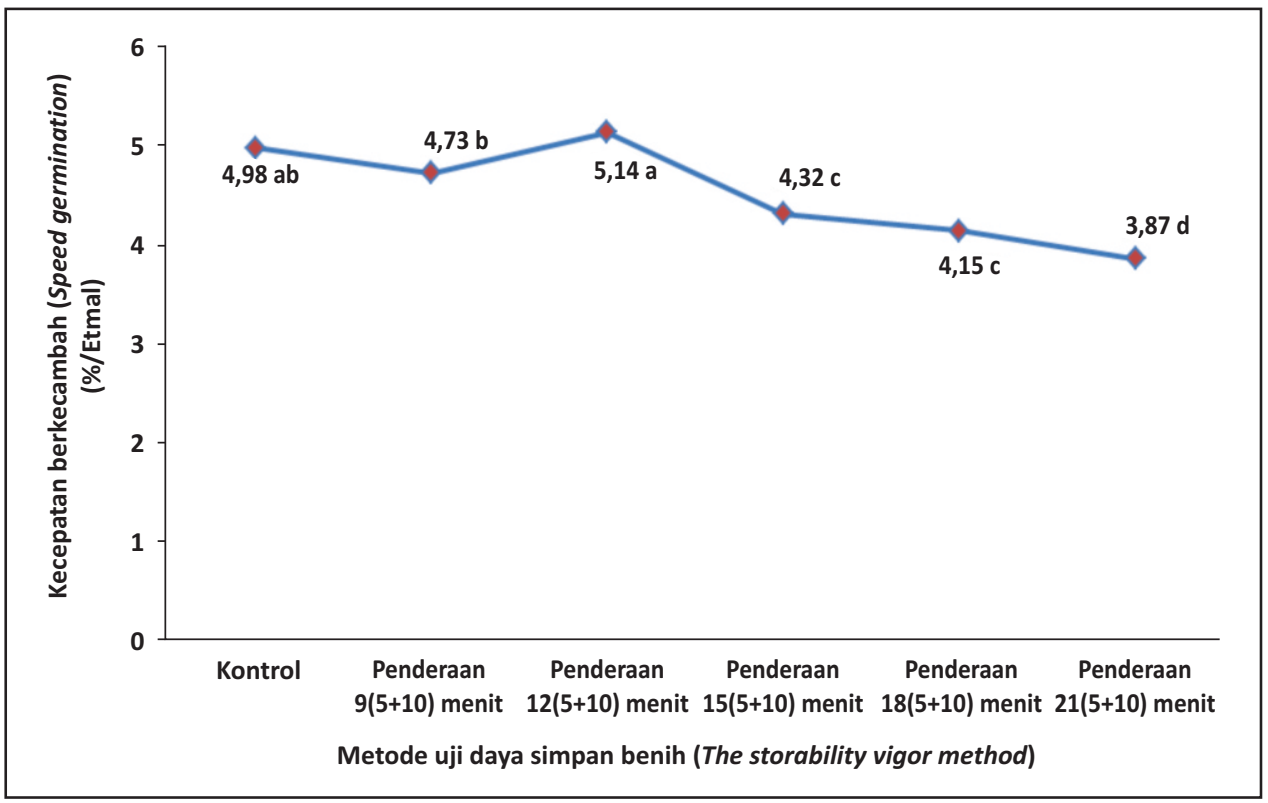

Keterangan(Remaks): Angka-angka yang diikuti oleh huruf yang sama menunjukkan tidak adanya perbedaan nyata pada tingkat kepercayaan 95\% (Values followed by the same letter are not significantly different at 95\% confidencelevel)

Gambar(Figure) 6. Kecepatan berkecambah A. crassicarpa berdasarkan metode uji vigor daya simpan (Speed germination of A. crassicarpa based on storability vigor method)

\section{B. Pembahasan}

\section{Vigor kekuatan tumbuh}

Dilihat dari nilai daya berkecambah dan kecepatan berkecambah (nilai vigor) setelah dilakukan uji vigor dengan metode Hiltner (uji tekanan), terjadi penurunan nilainya dan yang paling rendah nilai vigornya dihasilkan pada uji kejenuhan (kondisi gelap). Hal ini menunjukkan bahwa benih $A$. crassicarpa tidak dapat tumbuh dengan baik pada kondisi lahan yang gelap atau ternaungi. Pada umumnya kecambah akan tumbuh dengan baik jika cahaya cukup untuk kebutuhan fotosintesanya, sehingga nilai vigor pada uji kejenuhan akan menggambarkan potensi benih tersebut untuk tumbuh pada kondisi gelap, seperti lahan ternaungi (Zanzibar \& Pramono, 2009).

Masing-masing sumber benih, menunjukkan adanya perbedaan dalam kemampuan benih untuk mengatasi tekanan fisik dan kondisi gelap selama proses perkecambahan. Pada sumber benih KBS Riau dan KBS Sumatera Selatan memiliki nilai vigor yang lebih tinggi dibandingkan dari lokasi sumber benih APB Kalimantan
Selatan, APB Riau dan APB Jambi. Menurut Sutopo (2010), secara umum vigor diartikan sebagai kemampuan benih untuk tumbuh normal pada keadaan lingkungan yang sub optimal. Lot benih yang mempunyai vigor tinggi akan mampu bertahan pada kondisi yang ekstrim dan proses penuaan lambat dibandingkan dengan lot benih yang mempunyai vigor rendah. Lot benih krasikarpa dari KBS memiliki vigor benih yang lebih tinggi dibandingkan dengan sumber benih lainnya.

Salah satu tolok ukur yang digunakan untuk menilai vigor kekuatan tumbuh, yaitu kecepatan berkecambah (Rofik \& Murniati, 2008). Vigor benih yang tinggi dicirikan antara lain cepat dan merata tumbuhnya kecambah (Syafruddin \& Miranda, 2015). Dilihat dari nilai vigor kekuatan tumbuh relatif, pada masing-masing sumber benih tersebut menunjukkan adanya perbedaan dalam kemampuan benih untuk mengatasi tekanan fisik dan kondisi gelap selama proses perkecambahan. Benih A. crassicarpa yang berasal dari KBS Riau dan KBS Sumatera Selatan memiliki vigor yang lebih baik dibandingkan dengan benih yang berasal dari 
APB Kalimantan Selatan, APB Riau dan APB Jambi, yaitu vigor kekuatan tumbuh dari KBS dapat meningkatkan daya berkecambah sebesar $11 \%$ dan mempercepat kecepatan berkecambah sebesar $0,8 \%$ per etmal. Hal ini bisa disebabkan karena benih yang berasal dari KBS (sumber benih yang sudah dimuliakan) memiliki keragaman genetik yang lebih tinggi dibandingkan dengan APB (sumber benih yang belum dimuliakan), sehingga peluang proses inbreeding di APB semakin besar. Proses inbreeding dapat mengakibatkan benih yang dihasilkan memiliki viabilitas dan vigoritas yang rendah. Selain itu, kondisi pertumbuhan tegakan $A$. crassicarpa di lokasi KBS Riau dan KBS Sumatera Selatan lebih baik dibandingkan kondisi tegakan di lokasi APB Kalsel, APB Riau dan APB Jambi.

Untuk mendapatkan benih unggul, benih harus diperoleh dari sumber benih yang telah dimuliakan. Beberapa jenis tanaman hutan seperti Acacia mangium telah menghasilkan benih unggul pada tingkat KBS. Pada Pinus merkusii yang berasal dari KBS memiliki viabilitas dan vigor benih yang lebih baik dibandingan benih yang berasal dari tegakan benih teridentifikasi (Nurhasybi et al., 2008).

Benih bermutu adalah benih yang mampu berkecambah dalam kondisi yang cukup baik. Benih bermutu meliputi mutu fisik, fisologis dan genetik. Mutu fisik dan fisiologis merupakan cerminan dari rangkaian proses penanganan benih mulai dari proses produksi sampai pengecambahan benih. Mutu genetik diperoleh dari rangkaian kegiatan pemuliaan pohon (Yuniarti et al., 2015). Mutu fisik mencangkup ukuran, berat dan penampakan visual benih. Mutu fisiologis menggambarkan kemampuan berkecambah dan vigor benih sedangkan mutu genetik mencerminkan sifat-sifat unggul yang diwariskan oleh tanaman induknya yang berhubungan dengan pertumbuhan dan penampakan tegakan di lapangan. Mutu genetik sangat ditentukan oleh kondisi sumber benihnya. Kondisi sumber benih yang telah terseleksi atau teruji akan diperoleh kemajuan genetik yang bisa mempengaruhi produktivitas tegakan pada akhir daur (Nurhasybi et al., 2006). Hal ini sejalan dengan hasil penelitian pada benih $A$. Crassicarpa yang menunjukkan bahwa benih yang berasal dari mutu genetik yang tinggi, seperti KBS akan menghasilkan mutu benih yang lebih baik.

\section{Vigor daya simpan benih}

Pada koefisien penderaan hingga 18 kali terjadi peningkatan daya berkecambah dan kecepatan berkecambah pada masing-masing sumber benih. Hal ini dapat disebabkan karena uap etanol dalam jumlah tertentu memberikan pengaruh yang baik terhadap perkecambahan. Perlakuan uap etanol dapat berfungsi melunakkan kulit benih yang membantu memecahkan dormansi. Tetapi pada koefisien penderaan hingga 21 kali, vigor benih cenderung menurun. $\mathrm{Hal}$ ini berarti bahwa penderaan yang ditunjukkan untuk menggambarkan perbedaan viabilitas akibat penyimpanan hendaknya memakai taraf di atas $21(5+10)$ menit, maksudnya penderaan pada benih yang dilakukan selama 15 menit sebanyak 21 kali penderaan. Hal ini akan berimplikasi dalam penentuan kehilangan vigor daya simpan kelompok benih, dimulai setelah taraf tersebut, karena koefisien penderaan yang lebih rendah relatif sama pengaruhnya (tidak berbeda nyata). Setelah proses penderaan $21 \mathrm{kali}$, benih yang berasal dari KBS dapat menghasilkan nilai vigor lebih tinggi dibandingkan dengan APB. Vigor daya simpan benih dari KBS dapat meningkatkan daya berkecambah sebesar sebesar $12 \%$ dan mempercepat kecepatan berkecambah sebesar $0,84 \%$ per etmal. Angka ini signifikan karena dengan kecepatan berkecambah $0,84 \%$ per etmal, artinya dapat meningkatkan perkecambahan sebesar hampir 1\% kecambah normal setiap harinya. Hal ini berarti bahwa benih yang berasal dari KBS memiliki vigor daya simpan relatif yang lebih baik dari APB. Demikian halnya dengan KBS Riau dan KBS Sumatera Selatan, yang memiliki vigor daya simpan relatif lebih baik dibandingkan dengan APB Kalimantan Selatan, APB Riau dan APB Jambi. Perlakuan penderaan merupakan fungsi waktu, makin tinggi daya tahan benih terhadap perlakuan penderaan, benih tersebut memiliki daya simpan relatif yang tinggi. Perlakuan penderaan sangat berhubungan dengan perubahan kondisi lingkungan ekstrim, yaitu peningkatan suhu dan kelembaban nisbi, karena kedua faktor ini sangat penting pengaruhnya selama proses penuaan benih. Perlakuan deraan terhadap benih dengan pengusangan dipercepat merupakan simulasi daya simpan benih untuk kurun waktu tertentu. Deraan pengusangan cepat menyebabkan kadar air benih meningkat. Bila kondisi seperti ini berlangsung lama akan menyebabkan akumulasi asam lemak, sehingga mengakibatkan kerusakan membran sel (Tatipata, 2008). 
Pada sumber benih KBS Riau dan KBS Sumatera Selatan memiliki viabilitas dan vigor yang lebih baik dibandingkan dengan sumber benih APB Kalimantan Selatan, APB Riau dan APB Jambi. Hal ini dapat dipengaruhi oleh faktor keturunan (genetik) dari pohon induk atau sumber benih dan lingkungan. Menurut Milosevic et al. (2010), nilai yang diperoleh dari penentuan vigor dipengaruhi oleh susunan genetik benih, kondisi eksternal dimana pohon induk ditanam, kematangan benih saat panen, berat dan ukuran benih, kerusakan mekanik, penuaan, patogen dan lain-lain. Benih yang berasal dari pohon induk atau sumber benih yang berbeda akan mempunyai keragaman genetik yang berbeda dan mempunyai respon yang berbeda pula terhadap viabilitas dan vigor benihnya, sehingga antara lot-lot benih dalam satu jenis yang berbeda pohon induk atau provenannya ada kemungkinan berkorelasi dengan viabilitas dan vigor benih (Sudrajat, 2006). Pada KBS Riau dan KBS Sumatera Selatan memiliki kondisi pertumbuhan pohon induk yang lebih baik, kematangan benih lebih banyak, berat dan ukuran benih lebih besar, dibandingkan dengan APB Kalimantan Selatan, APB Riau dan APB Jambi.

\section{KESIMPULAN DAN SARAN}

\section{A. Kesimpulan}

Benih A. crassicarpa yang berasal dari sumber benih KBS Riau, KBS Sumatera Selatan memiliki vigor yang lebih baik dibandingkan dengan benih dari APB Kalimantan Selatan, APB Riau dan APB Jambi, yaitu vigor kekuatan tumbuh dapat meningkatkan daya berkecambah sebesar $11 \%$ dan mempercepat kecepatan berkecambah sebesar $0,8 \%$ per etmal dan vigor daya simpan dapat meningkatkan daya berkecambah sebesar $12 \%$ dan mempercepat kecepatan berkecambah sebesar $0,84 \%$ per etmal. Angka ini signifikan karena dapat meningkatkan perkecambahan sebesar hampir $1 \%$ kecambah normal setiap harinya.

\section{B. Saran}

Untuk meningkatkan viabilitas dan vigoritas benih $A$. crassicarpa, sebaiknya menggunakan benih yang berasal dari sumber benih KBS.

\section{UCAPAN TERIMA KASIH}

Penulis mengucapkan terima kasih kepada PT Arara Abadi di Riau, PT Wirakarya Sakti di Jambi, PT Musi Hutan Persada di Sumatera Selatan dan PT Inhutani II di Kalimantan Selatan atas kerjasama yang baik dalam memberikan materi genetik untuk penelitian ini. Terima kasih juga kami ucapkan kepada Dr. Darwo dari Pusat Penelitian dan Pengembangan Hutan yang banyak membantu dalam analisis data.

\section{DAFTAR PUSTAKA}

Aryunis. (2009). Penuntun pratikum teknologi benih. Fakultas Pertanian, Universitas Jambi, Jambi.

Bagod, S. (2006). Biologi sains dalam kehidupan. Surabaya: Yudhistira.

Ichsan, C.N. (2006). Uji viabilitas dan vigor benih beberapa varietas padi (Oryza sativa L.) yang diproduksi pada temperatur yang berbeda selama kemasakan. Jurnal Floratek, 2(1), 3742.

Lesilolo, M.K., Riry, J., \& Matatula, E.A. (2013). Pengujian viabilitas dan vigor benih beberapa jenis tanaman yang beredar di pasaran kota Ambon. Jurnal Agrologia, 2(1), 1-9.

Madauna, I.S. (2007). Vigor benih kacang hijau pada budidaya tanpa olah tanah dengan aplikasi pupuk fosfat dosis rendah yang ditanam setelah padi sawah. Jurnal Agroland, 14(3), 181-185.

Milosevic, M., Vijakovic, M., \& Karagic, D. (2010). Vigour tests as indicators of seed viability. Journal of The Serbian Genetic Society Genetika, 42(1),103-118.

Nurhasybi, Suita, E., \& Sudradjat D.J. (2006). Pengembangan sumber benih untuk pengadaan benih bermutu. Dalam: Prosiding Seminar Hasil-hasil Penelitian Balai Litbang Teknologi Perbenihan "Teknologi Perbenihan Untuk Pengadaan Benih Bermutu”,, Balai Litbang Teknologi Perbenihan, 77-85.

Nurhasybi, Sudrajat, D.J., \& Aisyah, P.S. (2008). Penentuan kriteria kecambah normal yang berkorelasi dengan vigor bibit tusam (Pinus merkusii Jungh et de Vriese). Jurnal Penelitian Hutan Tanaman, 5(1),1-11.

Rofik, A., \& Murniati, E. (2008). Pengaruh perlakuan deoperkulasi benih dan media perkecambahan untuk meningkatkan viabilitas benih aren (Arenga pinnata (Wurmb.) Merr.). Buletin Agronomi, 36(1),33-40. 
Syafruddin, \& Miranda, T. (2015). Vigor benih beberapa varietas jagung pada media tanam tercemar hidrokarbon. Jurnal Floratek, 10,1825 .

Sharifabad, H., \& Nodoushan, M. (2006). Salinityinduced growth and some metabolic changes in three salsola species. Journal of Arid Environments, 67,715-720.

Sutopo, L. (2010). Teknologi benih (Edisi Revisi Fakultas Pertanian UNIBRAW). PT Raja Grafindo Persada : Jakarta.

Sudrajat, D.J., \& Haryadi, D. (2006). Berat dan ukuran sebagai tolok ukur dalam proses sortasi dan seleksi benih tanaman hutan. Info Benih, 2(1),45-51.

Tatipata, A. (2008). Pengaruh kadar air awal, kemasan dan lama simpan terhadap protein membran dalam mitokondria benih kedelai. Buletin Agronomi, 36(1), 8-16.

Zanzibar, M., \& Pramono, A.A. (2009). Penentuan vigor kekuatan tumbuh dan vigor daya simpan relatif benih merbau, akor dan mindi. Jurnal Penelitian Hutan Tanaman, 6(3),145-155.

Yuniarti, N., Megawati, \& Leksono, B. (2013). Pengaruh metode ekstraksi dan ukuran benih terhadap mutu fisik-fisiologis benih Acacia crassicarpa. Jurnal Penelitian Hutan Tanaman, 10(3),129-137.

Yuniarti, N., Megawati, \& Leksono, B. (2015). Sortasi benih dengan ayakan untuk meningkatkan viabilitas benih Eucalyptus pellita F. Mull. Jurnal Penelitian Kehutanan Wallacea, 4(1), 35-40. 